\title{
UNIVERSAL SERVICE: NECESSARY CONSTITUTIONAL PROVISION FOR THE REFORM IN THE CHINESE ELECTRICITY INDUSTRY
}

\author{
Yang Liu*
}

\begin{abstract}
The experiences of the market reform in the EU and German indicates that the market competition will make the supply of the Universal Service in some regions more expensive, which will decrease the level of living standard of the people in the region. Therefore, the EU law and German Constitution have required that the government shall guarantee the Universal Service supply, especially when the market can not fulfill the duty. Poor power supply caused by market competition in certain regions would also happen in China during the reform in the Chinese electricity industry. In order to safeguard the living standard, the constitution needs to require on the issue of the guaranteed Universal Services, which will benefit the reform in the Chinese electricity industry.
\end{abstract}

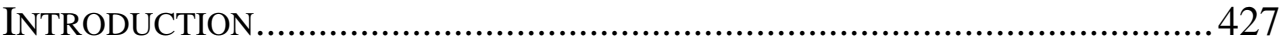

I. CONCEPT AND CONTENTS OF THE UNIVERSAL SERVICE........................428

II. The EuropeAn COMPETITION POLICY AND CONSTITUTIONAL PROVISION

ON THE UNIVERSAL SERVICE ..............................................................429

A. Competition Policy in the EU .............................................. 429

B. Constitutional Provision in Germany and in the EU............... 430

C. Exception .................................................................... 432

III. REFORM IN THE CHINESE ELECTRICITY INDUSTRY ............................432

IV. NECESSITY OF LEGAL PREPARATION FOR THE REFORM IN THE CHINESE

ELECTRICITY INDUSTRY ................................................................. 434

A. Constitutional Principles Supporting the Provision of the

Universal Service Guarantee.

B. Necessity of the Constitutional Guarantee of the Universal

Service in the Legal System.

C. Necessity of the Constitutional Guarantee for the Universal

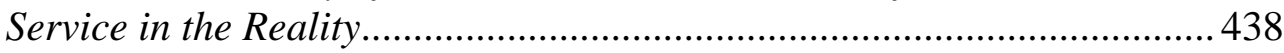

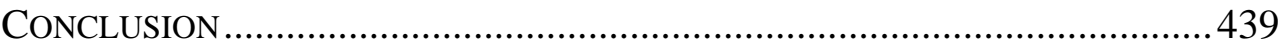

\section{INTRODUCTION}

The Universal Service is the abstractive concept of those services, which nowadays are necessary for the common livings of the people and

\footnotetext{
${ }^{*}$ Lecturer, Dr. jus., Law School, High Education Centre South, Guang Zhou, China PR. South China University of Technology, PRC. Research fields: Regulatory Laws.
} 
also are decisive for the standard of people's living conditions. Generally, the Universal Service includes post, telecommunication and railway services, electricity, water and gas supplies and the other infrastructure services. The constitutional provision on the Universal Service is required for the safety of infrastructure services, when related markets are privatized or liberalized.

Since the Chinese electricity market liberalization was planned by the central government, it is necessary that the Universal Service shall be required in the Constitution. That is the legal precondition of the Chinese electricity industry reform, which is learned from the experience of legal and market reforms inside the European countries, like Germany.

\section{CONCEPT AND CONTENTS OF THE UNIVERSAL SERVICE}

It is difficult to proscribe the detailed concept of the Universal Service, as there is no concrete given conception in the legal systems. Basically, the Universal Service is connected with the service of infrastructures like grid or telecommunication networks. But there are two significant differences between them. First, consumers of those infrastructures are not common people but specified groups or companies. Controversially, the Universal Service will be provided to the people directly; the people are consumers of the Universal Service. Second, service of infrastructures will be regulated by the government, especially the price of those infrastructure services. The price of the Universal Service, however, will not be regulated but monitored by the government or the authorized regulatory agencies ${ }^{1}$. Generally, the price of the Universal Service will be formulated in the market.

The Universal Service will determine the living standard of the people. Unquestionable, the Universal Service includes all necessary products and services in the modern society. They are the preconditions of modernization. For the people, the consumed Universal Services will indicate the standard of their living conditions. For example the consumption of electricity will predicate the usage of household electric machines; it will then directly indicate the level of the living standard of the people. Therefore, the Universal Service will become the benchmark of living standard ${ }^{2}$. Moreover, many Universal Services are not deprivable from the modern society. The Universal Services, like energy supply or telecommunication, are connected with modern day-life tightly. That is why, for many reasons, the Universal Service is also called as the Essential Service.

\footnotetext{
${ }^{1}$ G. Britz, in ENWG. 236 (Britz/Hellmann/Hermes eds., C.H.Beck 2009).

${ }^{2}$ J. Eekhoff, in REGULIERUNG IN DER ENERGIEWIRTSCHAFT 561 (Baur/Salje/Schmidt-Preuss eds., Carl Heymanns 2010).
} 
Contents of the Universal Service are wildly involved in the social economy. They include the basic supplement of electric power, natural gas, water and heat. Also they include the services of railway, telecommunication and post (not including express delivery). However, it does not mean that the Universal Service would be delivered to the people unconditionally. The economic reasonability is the precondition of the Universal Service. Meanwhile, some natural conditions like regional geography will be also decisive for the price level of the Universal Service.

\section{The European Competition Policy ANd Constitutional Provision ON THE UNIVERSAL SERVICE}

Constitutional provision on the Universal Service is not determined by the competition policy of the European Union, which will open the traditionally monopolized market to the competitors ${ }^{3}$. Meanwhile, the competition policy of the EU will demand that the basic supplements to the people shall be guaranteed by the government.

\section{A. Competition Policy in the EU}

The market opening inside the EU serves to construct a unified European market. Many Universal Services, the electricity supply for example, were traditionally monopolized by one or several suppliers before the market reform. The goal of this market construction is to create more market operators, which can deliver the service to the end consumers directly. At the same time, more competitors inside the market will bring in more pressures on the price decreasing, which will finally benefit the consumers at the end. Also the market competition will ensure that the demands of universal services will be fulfilled with a reasonable price ${ }^{4}$.

The beginning of a unified market was initialized by the discussion of more economic approach of the EU member states. In the unified European market, the arrangements of market construction are predominated by the competition policy. Because the people of the EU have the right to make profits from the unified market, since the most important goal of the EU unification serves to the interests of the Europeans, monopolized market shares of several operators will never be fit for the EU policy and the competition shall be introduced into the markets. The traditional isolated

\footnotetext{
${ }^{3}$ U. Immenga, Leitlinien als Instrument Europaeischer Wettbewerbspolitik, Referat in Rahmen der Vortragsreihe "RECHTSFRAGEN DER EUROPAEISCHEN INTEGRATION" 31 (University Bonn 2008).

${ }^{4}$ Y. Liu, Cost Orientation of the Grid Charge-Legal Comparison of the EU, German and Chinese Energy Laws 76 (AVM Munich 2011).
} 
regional markets, which will be only good for the monopolists, should be opened to the competitors and every potential competitor will then have the right to take the responsibility of the universal service supplements. The price will be finally formulated in the market, which was decided by the monopolists before this market opening.

However, the market opening has left one serious problem that the European governments can not force the market operators to deliver their services to those regions where the business profits can not cover the operation costs. In the market of electricity, for example, because of the geographic reasons the costs of electric power supply in certain regions will be dramatically higher than in the other areas. Thereafter, market operators, when they can determine their own business operation areas and their operation managements, will refuse the electricity supply in certain regions. They will only locate themselves in the regions, where they can make business profits. For the people in the high cost region, electric power would then be inaccessible or much more expensive than they can afford. As mentioned above, the supply of universal services will determine the living standard of the people. Thus, the market opening would make the people in certain regions to burden more costs, which will decrease their living standards and even the living conditions of those people in the region. As a result, the EU laws and the constitution of the EU member states shall guarantee that all people in the EU should receive the supply of adequate universal services ${ }^{5}$.

\section{B. Constitutional Provision in Germany and in the EU}

Right of adequate universal services belongs to the human right required by the international human right package of economic, social and cultural rights. Moreover, theoretically, the duty of the administration will demand that the government should take the responsibility to provide adequate supplements of the resources and services to ensure the social economy. The guarantee of the Universal Service is, therefore, the goal of constitutional provisions in Germany and in the EU. According to §§ 87e and $87 \mathrm{f}$ of the German Constitution (Grundgesetz), universal services of railway, post and telecommunication shall be safeguarded by the German government and private operators ${ }^{6}$. Those national provisions are to harmonize the EU requirements.

The main goal of those constitutional and legal provisions in Germany

\footnotetext{
${ }^{5}$ F. Saecker, in BerLinER Komm zum ENERgIERECHT 512 (Saecker ed., C.H.Beck 2010).

${ }^{6}$ K. Windthorst, in GRUNDGESETz KommEnTAR 332 (Sachs ed., C.H. Beck 2007).
} 
and in the EU is to avoid the situation that, after the market liberalization of related industries, competition will force private market operators get away from unprofitable regions, when those private operators are delivering universal services. Then those unprofitable areas will be isolated form the supply. In order to ensure the public interest and the common well, the government, therefore, shall guarantee the delivering of universal services for the people inside the country. This guaranteed delivery is required by the constitutional principles.

At the same time, private economy is, according to $\S \S 87 \mathrm{e}$ and $87 \mathrm{f}$ of the German Constitution, legally allowed to get involved in the supply of universal services. At the same time, the private operators can deliver their services independently in accordance with $\S \S 87 \mathrm{e}$ and $87 \mathrm{f}$ of the German Constitution. They will not be discriminated in the market and can be responsible for the obligatory universal service delivery, which is required and guaranteed by the government and the state-owned companies in the constitution. However, the delivery of universal serves of railway, post and telecommunication will be generally burdened by the state-owned companies in Germany.

Both state-owned and private market operators shall fulfill the legal requirements on the Universal Service delivery, especially the financial precondition of business operations, according to $\S \S 82,83,87$ German Telecommunication Act for example. This national requirement is to harmonize the EU regulation on the infrastructure investment (Article 6 (2) Directive 2004/67/EC).

It should be noticed that the German constitutional provision on the Universal Service does not include all necessary service, especially the electricity supply. The reason is simple. There is not a state-owned electricity supply company in Germany, which can take the responsibility of electric power supply nationwide. Thus, the requirement on universal service delivery can not be fulfilled by a state-owned company like in the telecommunication industry. This important universal service, namely the electric power sully, shall be supplied by the private market operators and the regional state-owned electricity suppliers. However, it is interesting, because the German constitutional previsions would also bring the opinion that the state-owned companies should be straightly connected with those obligatory universal services. State-owned companies in specified industry would, thereafter, burden more legal responsibilities than private companies, when the constitution has required on the guarantee of the Universal Service. 


\section{Exception}

Basically, the horizontal cooperation agreement of services will not be regarded as obstacles of market competition. The horizontal cooperation agreement is the agreement between or among the producers, the productions or services of who will construct the production chains. According to Article 81 (1) EC, the cooperation agreement will violate the EU policy and legal principles of market opening, when it will hinder the market competitions. However, the individual negative impact of the horizontal cooperation agreement in the market shall, in accordance with Article 81 (3) EC, be examined or analyzed ${ }^{7}$. It means that the horizontal cooperation agreement of services will not be judged as the violation of competition principle, when impacts of the agreement on the quality, variety or innovation of productions or services are not proved.

The network or infrastructure operator will violate the principle of competition, when the operator refuses to provide access services ${ }^{8}$. If the network or infrastructure user is willing to pay the standardized usage fee, the network or infrastructure operator shall, according to § 19 (4) No.4 German Competition Act for example, provide the access services. The operator shall not refuse the service delivery; otherwise it will be regarded as the violation of market competition principle required by the law.

As a result, in the electricity industry the competition policy and related legal requirements in the EU will permit the horizontal cooperation agreement among the electricity generators, the grid operator and the electric power retailers. The precondition that this horizontal cooperation agreement will not breach the legal requirements on fair market competition is that the agreement should not have impacts on the quality of electric power supply. Meanwhile, this horizontal cooperation agreement shall not be obstacle of the access service for other network users.

\section{REFORM IN THE CHINESE ELECTRICITY INDUSTRY}

Reform in the Chinese electricity industry was initialized by the decision of the Chinese central government. In the governmental plan, the principle of reform is to create competition in the power generation and retail markets. Therefore, those non-associative businesses of electricity supply companies will be unbundled. The operation of transmission and

\footnotetext{
${ }^{7}$ A. Ockenfels, in Regulierung IN DER ENERgIEWIRTSCHAFt 37 (Baur/Salje/Schmidt-Preuss eds., Carl Heymanns 2010).

${ }^{8}$ M. Schmidt-Preuss, in SonderdRucK Aus HANDBUCh DES StAATSRECHTS79 (Isensee/Kirchhof eds., Band IV Aufgaben des Staates, C.F.Mueller 2006).
} 
distribution networks will be separated.

The goal of reform in the Chinese electricity industry is identical with the electric power market liberalization in the EU. In the reform, competition plays an important role. Since the electric power generation and retail market after the reform will be open to all potential market players, the free market environment will allow the competitors to determine their own price of productions and services. According to the economic theory, only during the market competition the supplier of product or service can formulate the price, which will then be based on the operational efficiency. Under the pressure of market competition, the suppliers will face the risk that their supplement could not fulfill the quality demand of consumers and the inefficiency of supplement would also lead to a higher price, which will decrease their capacity of competitiveness. The precondition of a free market is that the price of electric power will be determined in the market. Therefore, the government will not set the price instead.

The main task of reform is to establish independent system operator of electric networks. When the grid is operated by an independent system operator, the retail price of electricity would not be influenced by the cost of networks. Thus, the retail price of electric power could be determined in the market freely. Furthermore, the independency of network operation and grid charge formulation will allow the potential electricity suppliers to take part in the market competition. More suppliers in the market will bring in more intensive market competition. Under the market competition, the price of electric power supply will be decreased and the end consumers will share the benefits of the reform ant the end. Therefore, the final goal of reform in the electricity industry is to decrease the price of power and to increase the market competition.

The market reform in the electricity industry is, however, not systemized. As mentioned above, a free market will leave behind many vacuum areas of electric power supply, because under the competition pressures every market player will strive to achieve business profits; otherwise, these market players will not survive from the market competition. Meanwhile, the government can not order the market players to deliver the basic power supply, since in the free market economy private market operators do not have any responsibilities to do so. Nevertheless, the Chinese Constitution and laws do not require that the government shall be responsible for the basic supply of the Universal Service, which will guarantee the common living standard of the people in China. In brief, the legal system has not prepared for the reform in the Chinese electricity industry; more essential provisions and requirements on the Universal 
Service should be added before the reform has been happened.

Furthermore, the market reform in the Chinese electricity industry can not be achieved in a short term, since there are many obstacle and difficulties in the practice. On one side, the whole retail market of electric power is monopolized by the state-owned electricity supply companies. The reform will force them to share the retail markets to other potential suppliers. On the other side, the business profits of electric power retail markets are not parallel. Business profits between urban and rural areas are quite different. It is quite possible that all potential market competitions would be taken place in the metropolises and central cities. The rural regions would be the red pock of electricity supply at last, as the power retail in urban regions is more lucrative. That is what the reform in the Chinese electricity industry needs to avoid.

As a result, the legal pre-requirement for the reform in the Chinese electricity industry is to guarantee the electric power supply for all the people in the country, as no one will then be left behind in the market reform. The market design, no matter the macrostructure or the microstructure, shall obey the principle that the market competition shall ensure the social fairness and the people's right of the Universal Service shall be guaranteed.

\section{NECESSity of LEgAL PREPARATION FOR THE REFORM IN THE CHINESE ELECTRICITY INDUSTRY}

The Constitutional provision on the Universal Service guarantee is required by the principle of the Chinese Constitution. Moreover, it is demanded by the reality of the reform in the Chinese electricity industry.

\section{A. Constitutional Principles Supporting the Provision of the Universal Service Guarantee}

The provision of the guaranteed Universal Service can not be found in the Chinese Constitution, because the amendment of the Chinese Constitution was before the plan of reform in the Chinese electricity industry had been planned. The latest amendment of the Chinese Constitution did not concentrated on the issue of the market reforms at that time. Also there were even no detailed discussions on the possible results of the reform in the Chinese electricity industry, which could initialize the possible amendment of the Chinese Constitution. It is totally a blank about the legal requirements preparing the reforms.

However, the guarantee of the Universal Service can be abstracted 
from the principles of the Chinese Constitution, which will be discussed as following:

First, the guarantee of the Universal Service is required by the principle of the Equal Treatment. The equal treatment means non-discrimination. It is one of the predominate principles in the constitution, which ensures that everyone will be handled equally by the law. For this reason, the constitution shall provide a basic equal treatment provision for the living standard of the people, which will ensure that the people in the whole country, even though there are economical and physical differences among different regions, would like to have the right and the capacity of demand on those basic supplements. Because of the regionally economical and physical differences, the fulfillment of those supplies would be just relative equal. However, the rights of the people to have those services will indicate the non-discrimination in the society. It is also necessary for the fairness, which would be achieved with equal treatment. By this means, the equal treatment will not only connect with the political opportunity, but also the economic power.

Second, the guarantee of the Universal Service is required by the principle of the state ownership. The state ownership is also called as the public ownership, which will be represented and managed by the government. It is the people, who are the real owner of those properties. For this reason, the state owned properties shall serve the interests of the people, which mean that those state-owned companies shall be implemented as the means of the Universal Service supplements. Only when the state-owned electric power companies should deliver the demanded power supply to the people, their duties as public owned properties would be fulfilled. The main difference between the Chinese and the west countries' economy is the domination of the state-owned companies in the industries of related universal services. Therefore, the public ownership of those companies will demand that the interest of the owner should be supplied firstly. The government shall, thereafter, make sure that the delivery of the Universal Service from state-owned companies would be guaranteed, as the government is legally the representative of the state ownership. Noticeable is that the German constitution has already settled down the example of the duty of stat-owned company on the supply of universal services. Since there are no differences between the German and the Chinese state-ownership of companies, the duty of Chinese state-owned companies should be certainly comparable to those duties burdened by the German counterparts. Guaranteed electric power supply will be just depended on the decision of the Chinese central government, because the government will determine the 
function and role of these state-owned companies in the macro economy.

Third, the guarantee of the Universal Service is required by the principle of the socialist market economy. Principle of the socialist market economy includes two subsections. The first subsection is the socialism, which is determined by the state ownership illuminated above. The second subsection is the market principle, which shall also obey the principle of socialism. The socialist market economy is, therefore, characterized with the state ownership, which will serve to fulfill the demands of the people. The state-owned electricity power companies, for example, will be used as the implementation of the Universal Service supply in the electricity industry. Furthermore, the socialism will focus on the fairness among the people, which will require that the basic supply of the Universal Service to the people shall be comparable in different regions. People in the different areas will, according to the principle of socialism, be handled equally and fairly. When the basic supplements of the Universal Service, at the same time, obey the principle of market economy, it will then meet the demand of the principle of the socialist market economy. Thus, the socialist market economy principle will encourage the supplements of the Universal Services to fulfill the requirements on fair supply to the people.

Fourth, the guarantee of the Universal Service is required by the principle of human right. The human right is called as the right of the people. The most important human right is the people's right of living. And the people's right of living is decided by the economic character of the nation, which means that the socialist market economy should safeguard the people's right of living in China. As mentioned above, the supply of the Universal Services will determine the living condition and common living standard of the people in certain society. To provide enough standardized universal services will, therefore, ensure the basic living standard of the people. As a result, the Chinese Constitution and its principle of the human right will order the government to implement adequate measure and appropriate methods to guarantee the supply of the Universal Services.

All in all, those principles in the Chinese Constitution have already indicated that the Universal Service in China shall be guaranteed by the government. The people will have the right to be supplied with adequate universal services. Electricity supply, which is the most important universal service for the people, shall then be safeguarded by the government, when the reform in the Chinese electricity industry will change the aged supply chain. If the electric power supply would be jeopardized by the reform, the government should, according to the constitutional principles, take the responsibility of supplement by itself, when it was necessary. 
B. Necessity of the Constitutional Guarantee of the Universal Service in the Legal System

The constitutional guarantee of the Universal Service is necessary for the amendment of the Chinese Constitution. As illuminated above, the reform in the Chinese electricity industry, possibly also in other industries related to the Universal Services, would make the electric power supply in some regions poorer or more expensive. Therefore, the government shall have the responsibility to deliver the basic universal services to the region. However, the Chinese Constitution does note require on those governmental obligations. In order to guarantee that the people in the whole country would receive comparable equal treatment of the electric power supply, an amendment about the obligatory electric power supply of the government will be decisive for the reform in the Chinese electricity industry; otherwise, the market competition in some special regions would impact the living standard of the people negatively.

The constitutional guarantee of the Universal Service is necessary for the related law makings. In order to accomplish the reform in the Chinese electricity industry, there will be also a legal reform, which will provide detailed implementations of the universal service delivery or supply. If the constitutional guarantee of the Universal Service had been already required, the related law making would be much easier, especially when the law would require on the duty of the governmental guarantee of the universal service delivery or supply. If the governmental guarantee of the universal service delivery or supply were not clear and provided by the constitution, the duty settlement would face the conflicts with other constitutional principles.

The constitutional guarantee of the Universal Service is necessary for the making of governmental provisions. In order to implement the detailed requirement on the universal service guarantee, governmental provisions will be important. The government will then require the concrete clauses about the delivery or supply of universal services. Meanwhile, the constitutional principle will direct those detailed governmental provisions, which will be regarded as the implementations of the required constitutional principle. Without any appropriate and adequate principles, the constitution will lose its control on the concretization of the Universal Service supply, which will lead unpredictable legal consequences or legal conflicts. For example, the Chinese Constitution has settled down the principle of independent management of state-owned companies, which is implemented with the Chinese Company Law. Without constitutional provision on the 
obligatory supply of the Universal Service, the state-owned company can refuse to fulfill the duty, because their right of independent management is constitutionally and legally safeguarded. Then the government will lose its means for the Universal Service delivery. This possible conflict between the provisions on the management independency and the Universal Service supply could even be solved by the clause of guarantee of the Universal Service in the Constitution.

As a result, constitutional provision will ensure that the required Universal Service guarantee burden by the government and all those detailed governmental provisions concretizing the obligatory duties of the government would obey the principles set by the law makers.

\section{Necessity of the Constitutional Guarantee for the Universal Service in the Reality}

The fundamental reason of the Constitutional Guarantee for the Universal Service of the people is the importance of those services. As motioned above, the Universal Service is absolute necessary for the common living condition of the people nowadays. The usage of the universal services, for example the telecommunication serve, will indicate the living standard of the people and the level of their economic power. It is unimaginable that the some basic service such as electric power supply would be dispatched from the modern age. Thus, to ensure the supply of the Universal Service is to guarantee the living condition and to improve the living standard of the people, which now is self-understanding the basic obligation of the government in according to the theory of the right of governing.

As mentioned above, reform in the electricity industry will bring in more potential market competitions in the urban power retail markets, which will leave behind the electricity supply in the rural areas as black holes. In order to fulfill the demands of power supply in the rural regions, the government will take the responsibility. However, the government shall not force market operators to bring their services to the rural regions, because the constitution and the law will protect the economic interests of those electricity suppliers. As a result, it is the government that shall take the responsibility of electricity supply, when market operators are unwilling to do so. The power supply in the rural areas will be obligatory in those regions. Nevertheless, the obligatory supply of power should be accomplished by the government directly. In the practice, the government can use other means to fulfill the task, for example the state-owned 
electricity supply company. But this method brings other problem, since the state-owned electricity supply companies are economically independent juristic persons and have their own economic interests. That causes the possible legal conflicts mentioned above. In accordance with the Constitution and the Company Law, the government should not rule the business operation and management of the company directly. Therefore, those state-owned electricity supply companies and even the government can refuse to deliver the supply of the Universal Service, since the obligatory electricity supply is not required by the constitution.

Moreover, even the Universal Service is not mentioned in the Chinese Constitution or laws. Thus, the responsibility of the government of basic delivery of the universal services will not guaranteed, when the related industries and markets will be reformed. Many regions, when the supply of service is not profitable, will be left alone and the people of those regions could not even share the basic supplement of power or water, since there is no legal preparation for the reform in the Chinese electricity industry.

In order to achieve the social fairness of the universal service supplements, the Chinese constitution has to add detailed provisions on the Universal Service that the government shall take the responsibility to guarantee the basic supply like electricity in the whole country, when the markets will be open to the competitions. The state-owned companies could be used, therefore, to serve the achievement of those obligations firstly. Also the Constitution needs to mention that the private economy is welcomed to take the responsibilities of the Universal Service, but the government shall not force them to fulfill the responsibility in certain areas, especially when the business operation in certain regions is economically unreasonable.

Thereafter, there shall be a balance between the unprofitable supplement in certain regions and the fulfillment of obligatory electricity supplies. In the practice, the government would then tolerance the dominant market position of the state-owned electricity supply companies, as the business profits made by the dominant market position should be used to subsidize the costs of power supply in the rural regions. As a result, the dominant market position of state-owned electricity supply companies will not be challenged by other market operators in the reform and the stateowned electricity supply companies must therefore burden the obligatory electricity supply in unprofitable areas.

\section{CONCLUSION}

A constitutional provision on the guarantee of the Universal Service for 
the people is demanded by the reform in the Chinese electricity industry, because in the market competition unprofitable supply region of electric power will not be welcomed by the market players. Therefore, the government shall take the responsibility of power supply in those regions, when market players are unwilling to do so. Such a guarantee will ensure that all regions in the country will be supplied with sufficient electric power, which can fulfill the demands of consumers. This is the implementation of social fairness and required by the principles of the Chinese Constitution. 